\title{
Exploring South African adolescents' knowledge of abortion legislation and attitudes to abortion: Sexual status and gender differences
}

\author{
D Ramiyad, MSocSc (Health Promotion); C J Patel, MA (Counselling Psychology) \\ School of Applied Human Sciences, University of KwaZulu-Natal, Durban, South Africa \\ Corresponding author: C J Patel (patelc@ukzn.ac.za)
}

\begin{abstract}
This study explored adolescents' knowledge of the Choice on Termination of Pregnancy Act (No 92 of 1996) and attitudes toward abortion. A sample of 150 secondary school learners (aged 15 - 19 years), from a low socioeconomic area in Durban, KwaZulu-Natal Province, South Africa was surveyed. Twenty percent of the sample indicated that they found abortion acceptable. The sexually active (have had sex) respondents had more positive attitudes toward abortion for elective reasons than the sexually inactive (have not had sex) sample. On traumatic reasons the gender difference was found to be a function of sexual status. Sexually active females showed greater support than males. While the majority of those sampled were aware of the legal status of abortion in this country, they demonstrated a lack of knowledge on specific aspects of the Act. Recognition of adolescents' right to information is central to responsible decision-making among the youth about sexual and reproductive health issues.
\end{abstract}

S Afr J Child Health 2016;10(2):105-106. DOI:10.7196/SAJCH.2016.v10i2.1137

For public health initiatives to be realised, there needs to be greater recognition of adolescence as the life phase in which adult health behaviours are set. ${ }^{[1]}$ South Africa (SA)'s National Adolescent Sexual and Reproductive Health and Rights (ASRH\&R) framework strategy $(2015)^{[2]}$ sets out the country's commitment to improving the sexual and reproductive health of its youth.

There are a number of governmental efforts (including the national Department of Education's attempt at improving knowledge and skills of SA youth through life orientation (LO) subjects at school) and non-governmental initiatives aimed at addressing youth sexual and reproductive health ${ }^{[3]}$ Most of these are designed to tackle youth susceptibility to HIV and AIDS. The Choice on Termination of Pregnancy (CTOP) Amendment Act (No. 1 of $2008)^{[4]}$ allows SA women (including teenagers) the legal right to terminate pregnancies. The ASRH\&R framework (2015) ${ }^{[2]}$ reports lack of knowledge about legal rights relating to sexual health and risks, particularly on termination of pregnancy and emergency contraception, as one of the emerging trends in research findings and identifies it as one of the challenges impeding progress in the field of sexual and reproductive health. Twenty-five percent of all unsafe abortions in sub-Saharan Africa are carried out on girls aged between 15 and 19 years. ${ }^{[1]}$ Apart from the study of grade 11 learners in the Eastern Cape Province, ${ }^{[5]}$ research studies aimed at gauging knowledge of abortion legislation among the youth in this country appear to be rather limited. The aim of the present study was to explore gender differences in knowledge of CTOP legislation and attitudes to abortion in a small sample of adolescents from a low socioeconomic suburb in the KwaZulu-Natal (KZN) area.

\section{Methods}

A survey was conducted using a convenience sample of 150 ( 89 female and 61 male) learners aged 15 - 19 years, from a secondary school in a low socioeconomic suburb in the Durban area. The self-administered questionnaire contained three sections: $(i)$ biographical information, which covered age, gender and sexual status (have had sex/have not had sex); (ii) a measure of abortion attitudes using a 7-point response format ranging from 'strongly disapprove' (1) to 'strongly approve' (7) $;{ }^{[6]}$ (iii) a set of 13 questions based on the Termination of Pregnancy
Act No. 92 of 1996, assessing knowledge of various components of the SA abortion legislation as devised by D Ramiyad.

Ethical clearance was obtained from the Faculty of Humanities, Development and Social Sciences, University of KZN and permission to access the school site was provided by the relevant authorities.

Signed parental consent for 159 grade 11 learners was received. The questionnaires were administered in the LO class, a holistic class that focuses on the emotional, physical, spiritual, moral and cultural development of learners. A total of 150 complete questionnaires were used in the study. The abortion attitude items were subjected to a principal components analysis with varimax rotation. In order to assess group differences, $2 \times 2$ (gender $\times$ sexual status) analysis of variance (ANOVA) was conducted on the attitude scales and the knowledge measure. SPSS software (IBM Corp., USA) was used for the analyses.

\section{Results}

Two factors were extracted from the analysis of the abortion items:

- Elective reasons for abortion: (choice linked to low income, not wanting more children, single status, personal decision) with loadings ranging from 0.63 to 0.80

- Traumatic reasons for abortion: (rape, poor health, fetal defects), with loadings ranging from 0.68 to 0.78 .

These factors were treated as subscales in further analyses. The results of the tests of difference (gender and sexual status) are presented in Table 1. No gender or sexual status differences were found on the knowledge items. The results showed that:

- although $80 \%$ of the sample was aware of the legal status of abortion in this country, they showed limited knowledge of specific aspects of the Act

- $10.7 \%$ were aware of the period of gestation when termination is allowed

- $6.7 \%$ knew the age at which a person could request an abortion without parental permission

- $20.7 \%$ were aware of the different methods of abortion

- $28.7 \%$ knew who is allowed to perform the procedure

- $29.3 \%$ were aware that it is a criminal offence to prevent or obstruct access to a legal abortion. 
Table 1. Gender by sexual status: ANOVA results of knowledge, elective reasons, traumatic reasons

\begin{tabular}{|c|c|c|c|c|}
\hline & $\begin{array}{l}\text { Male } \\
(N=61), \\
\text { mean (SD) }\end{array}$ & $\begin{array}{l}\text { Female } \\
(N=89), \\
\text { mean (SD) }\end{array}$ & $\begin{array}{l}\text { Total, } \\
\text { mean (SD) }\end{array}$ & $f$-test \\
\hline \multicolumn{5}{|l|}{ Knowledge } \\
\hline Gender & $5.51(2.77)$ & $5.92(2.49)$ & & 1.26 \\
\hline Sexual status & & & & 0.77 \\
\hline Yes & $5.75(3.10)$ & $6.05(2.31)$ & $5.86(2.82)$ & \\
\hline No & $5.05(1.99)$ & $5.87(2.57)$ & $5.68(2.46)$ & \\
\hline Gender by sexual status & & & & 0.28 \\
\hline \multicolumn{5}{|l|}{ Elective reasons } \\
\hline Gender & $14.40(5.11)$ & $12.36(6.40)$ & & 0.54 \\
\hline Sexual status & & & & $7.47^{\star}$ \\
\hline Yes & $15.33(4.85)$ & $14.64(6.32)$ & $15.08(5.39)$ & \\
\hline No & $12.47(5.20)$ & $11.58(6.29)$ & $11.78(6.04)$ & \\
\hline Gender by sexual status & & & & 0.01 \\
\hline \multicolumn{5}{|l|}{ Traumatic reasons } \\
\hline Gender & $11.43(3.68)$ & $12.93(5.10)$ & & $4.40^{\dagger}$ \\
\hline Sexual status & & & & 0.15 \\
\hline Yes & $10.86(3.17)$ & $14.71(4.70)$ & $12.28(4.21)$ & \\
\hline No & $12.56(4.41)$ & $12.34(5.13)$ & $12.39(4.95)$ & \\
\hline Gender by sexual status & & & & $5.48^{\dagger}$ \\
\hline $\begin{array}{l}{ }^{*} p<0.01 . \\
{ }^{\dagger} p<0.05 .\end{array}$ & & & & \\
\hline
\end{tabular}

Compared with the study using a similar age group,${ }^{[5]}$ a higher percentage of the present sample was aware of the obligatory pre- and postcounselling offered to women. On the whole, however, similar findings were observed across the two studies. In the present sample, those respondents who had had sex were significantly more supportive for elective reasons than those who had not had sex. A gender by sexual status interaction effect was observed on the traumatic reasons subscale with difference in gender dependent on whether they had had sex or not: females of the former group opposition to the availability of legal abortion in this country.

\section{Conclusion}

Although this sample does not claim to represent the youth of South Africa, the findings correspond with the emerging pattern of lack of information and low levels of support for abortion from other studies. Among recommendations ${ }^{[1]}$ regarding adolescent health in general is the importance of understanding adolescence in terms of a life-course perspective, of co-ordinated multi-pronged initiatives, of establishing efficient information systems, and of giving adolescents a stronger voice by involving them in identifying their concerns and in finding the solutions. Recognition of the right to information as the most basic aspect of reproductive rights ${ }^{[5]}$ should be central in the LO classes offered in schools and in the efforts of non-government organisations if youth knowledge and awareness is to improve.

\section{References}

1. Sawyer SM, Afifi RA, Bearinger $\mathrm{LH}$, et al. Adolescence: A foundation for future health. Lancet 2012;379(9826):1630-1640. DOI:10.1016/ S0140-6736(12)60072-5

2. National Department of Social Development, South Africa. National Adolescent Sexual and Reproductive Health and Rights Framework Strategy. 2015. http://www.dsd.gov.za/index2 $\mathrm{php}$ ? option $=$ com_docman \& task $=$ doc view\&gid $=578 \&$ Itemid $=3 \quad$ (accessed 10 April 2015).

3. Beksinska ME, Pillay L, Milford C, Ranchod V. The sexual and reproductive health needs of youth in South Africa - history in context. S Afr Med J 2014;104(10):676-678. DOI:10.7196/SAMJ.8809

4. Choice on Termination of Pregnancy Amendment Act No 1 of 2008. http://www.gov.za/sites/www. gov.za/files/a1-08.pdf (accessed 10 April 2015).

5. Macleod C, Seutlwadi L, Steel G. Cracks in reproductive health rights: Buffalo City learners' knowledge of abortion legislation. Health SA Gesondheid 2014;19(1). DOI:10.4102/hsag. v19i1.743

6. Esposito CL. Basow SA. College students attitudes toward abortion: The role of knowledge and demographic variables. J Appl Soc Psychol 1995;25(22):1996-2017. 